\title{
Belt and Road Initiative in China: The Impact of Real Openness on Service Trade
}

\author{
Siqin Yu, Siqi Sun \\ School of Economics and Management, Shanghai Maritime University, Shanghai, China \\ Email:sqsun@stu.shmtu.edu.cn
}

How to cite this paper: Yu, S.Q. and Sun, S.Q. (2019) Belt and Road Initiative in China: The Impact of Real Openness on Service Trade. American Journal of Industrial and Business Management, 9, 1431-1445. https://doi.org/10.4236/ajibm.2019.96094

Received: May 11, 2019

Accepted: June 27, 2019

Published: June 30, 2019

Copyright $\odot 2019$ by author(s) and Scientific Research Publishing Inc. This work is licensed under the Creative Commons Attribution International License (CC BY 4.0).

http://creativecommons.org/licenses/by/4.0/

\begin{abstract}
This paper investigates the linkages between real openness and service trade under the belt and road initiative. Three dimensions including competitiveness, growth rate of services export and proportion of emerging services are used to measure service trade. Covering the period of 1995-2016 and using vector-error correction (VEC) model and impulse response functions (GRIFS), we find that a general long-run equilibrium relationship among the service trade, the openness, the human capital and the import and export of the goods, as well as a short-run relationship. The results of this study indicate that real openness plays an important role in implementing the belt and road initiative. The competitiveness and growth rate of service trade in China are increasing while the emerging services has no improvement under the belt and road initiative.
\end{abstract}

\section{Keywords}

Service Trade, Belt and Road, Real Openness, China

\section{Introduction}

The belt and road initiative has been in effect for five years now since its first release in October 2013. Currently, the "anti-globalization" and trade protectionism are re-emerging. In this case, the belt and road initiative is a recent strategic shift in China's foreign policies, aiming to "going-out". The focus on service trade is required to ensure that belt and road initiative promotes sustainable development. Specifically, the implementation of the belt and road programs for services includes increasing direct investments in projects, as well as investments in science and technology cooperation. For example, in 2016, the import and export of service trade in China along the "Belt and Road" countries and regions reached 122.2 billion dollars, accounting for 15.2 percent of the total trade. The 
contract of the foreign engineering amounts to 12.3 billion dollars, an increase of nearly 40 percent year-on-year. Up to April 30, 2019, China has signed 187 cooperation documents with 131 countries along the belt and road. From the year of 2013 to 2018, the total volume of imports and exports between China and the "belt and road" countries has reached US $\$ 6469$ billion, and foreign direct investment has exceeded US $\$ 80$ billion, which is supported by the belt and road initiative.

Given the fact that new initiative focuses on the international service trade cooperation, we believe there is a need for an in-depth study on the impacts of openness on economic growth as well as service trade. The costs and benefits of openness to international trade for economic growth have been studied extensively [1] [2] [3] [4]. M Jansen and R Piermartini find that a 10 percent increase in the temporary people movement contributes to a 4.7 percent increase in total service trade and 7 percent increase in the inflows and outflows of foreign direct investment (FDI) [5]. Markusen puts general equilibrium and dynamic model together to figure out the opening market increases the amount of the services [6]. Using a gravity model analysis, LG Liu considers that financial service trade liberalization in China has set impetus for accelerated domestic financial liberalization under the WTO regulations [7]. EK Lim and $\mathrm{Z}$ Chen find telecommunications does not seem to have a significant effect on investment in low-risk countries [8]. Chen Jiyong suggests that China and the countries along "Belt and Road" should deepen reform to increase the openness of economy [9]. Using a computable general equilibrium (CGE) model, Zhang, Lingge points that further import tariff reduction may harm the domestic production and there are still rooms to improve national economy and increase the consumer utility by trade liberation [10]. Matheus $\mathrm{K}$ finds trade openness has a positive effect on energy consumption, which means it is necessary to carry out more liberalization and deregulation policies to incent the trade and economy liberalization [11].

However, it does not mean that China is a powerful service trade country although the openness contributes to the economic growth and trade in service. Furthermore, spates of empirical studies use the competitiveness to measure the quality of service trade [12] [13] [14]. Subsequently, Yao Zhanqi points out the competitiveness is too single to measure a powerful country in international trade [15].

Therefore, our study contributes to the literature in two ways. First, we believe that this is by far the first empirical study on the relationship between openness and service trade under the belt and road initiative. Second, we use the three variables, instead of one variable, to investigate service trade in China effectively. The aims of this paper are to understand the current trends of the service trade in China, and to appraise whether the belt and road initiative impacts service trade through real openness. To serve these objectives, the following three tasks are set up. First, we will provide a clear perspective on service trade with regard to its general development, structure and sub-sector. Second, we will construct 
measures of real openness and competitiveness for the following empirical models. Finally, we will employ the vector-error correction (VEC) model and impulse response functions (GRIFS) to estimate. The real openness is introduced to test whether it has a positive impact on service trade under the belt and road initiative.

The paper is organized as follows. Section 2 provides an overview of service trade in China from three aspects: the trends, the proportion of service trade comparing to goods trade and the service trade category. Section 3 outlines the data source used in the analysis and describes the variables in more details, including independent variable, dependent variables, control variables and dummy variable. Section 4 presents the methodology and empirical results and this is followed by a section containing a conclusion of our results.

\section{Service Trade in China}

Service trade has been an important factor for the development of the economic growth. For example, in 2017, the value-added of service industry in China is 8 percent higher than that of the previous year, 1.1 and 1.9 percent higher than GDP and second industry, respectively. The total import and export of services is 46,991 billion yuan, up 6.8 percent over the previous year. However, the total import and export of goods is 277,923 billion yuan in 2017 , which is 14.2 percent higher than that in 2016 and 7.4 percent higher than service trade at the same period (China, National Bureau of Statistics, 2017).

Table 1 presents the evolution of service trade and the goods trade in the period of 1995-2016. The service trade has increased annually. Both the import and export are increasing steadily (see Column (2) and Column (3) of Table 1). However, the growth rate is unstable and it even has a negative growth (see Column (4) and Column (5) of Table 1). In 2016, the growth of services import and export are 3.82 percent and -4.26 percent respectively, and the gap between them is 9.07 percent, higher than that in 2015 (1.31\%).

Although the total service trade value (both in export and import) has been increasing significantly (see Table 2), the share of the service trade is small in comparison with merchandise trade value (see Column (4) and Column (5) of Table 2). In 2016, the share of the service trade is 15.1 percent while the merchandise trade is 84.9 percent. However, the growth of the service trade is rising faster than that of the merchandise trade (see Column (6) and Column (7) of Table 2). The latter has become negative since 2012 while the former is positive. From this perspective, the development of service trade in China is better than merchandise trade in the long run.

The deficit in services trade has lasted for many years and is advancing year after year. Table 3 presents the sub-sector of service trade in 2017. In terms of net export, the total value is -2395 billion dollars and the travel is -2161 billion dollars, which accounts for 90 percent (see Column (8) of Table 3). Travel becomes the top of service trade deficit. Followed by it is transportation, with the proportion of 23 percent. On the contrary, there are many other sectors with a 
Table 1. The trends of the service trade in China, 1995-2016 (Million \$).

\begin{tabular}{|c|c|c|c|c|c|c|}
\hline \multirow{2}{*}{ Year } & \multicolumn{2}{|c|}{ Service Trade } & \multicolumn{2}{|c|}{ Growth Rate } & \multicolumn{2}{|c|}{ Share } \\
\hline & Export & Import & Export & Import & Export & Import \\
\hline 1995 & 19,444 & 24,636 & ----- & ----- & 0.441 & 0.559 \\
\hline 1996 & 21,698 & 22,370 & 0.116 & -0.092 & 0.492 & 0.508 \\
\hline 1997 & 25,852 & 27,725 & 0.191 & 0.239 & 0.483 & 0.517 \\
\hline 1998 & 25,192 & 26,468 & -0.026 & -0.045 & 0.488 & 0.512 \\
\hline 1999 & 27,604 & 30,968 & 0.096 & 0.170 & 0.471 & 0.529 \\
\hline 2000 & 31,804 & 35,860 & 0.152 & 0.158 & 0.470 & 0.530 \\
\hline 2001 & 34,711 & 39,034 & 0.091 & 0.089 & 0.471 & 0.529 \\
\hline \multirow{2}{*}{ Year } & \multicolumn{2}{|c|}{ Service Trade } & \multicolumn{2}{|c|}{ Growth Rate } & \multicolumn{2}{|c|}{ Share } \\
\hline & Export & Import & Export & Import & Export & Import \\
\hline 2002 & 41,547 & 46,082 & 0.197 & 0.181 & 0.474 & 0.526 \\
\hline 2003 & 48,953 & 54,855 & 0.178 & 0.190 & 0.472 & 0.528 \\
\hline 2004 & 68,083 & 72,193 & 0.391 & 0.316 & 0.485 & 0.515 \\
\hline 2005 & 77,974 & 83,348 & 0.145 & 0.155 & 0.483 & 0.517 \\
\hline 2006 & 93,492 & 100,332 & 0.199 & 0.204 & 0.482 & 0.518 \\
\hline 2007 & 124,895 & 128,269 & 0.336 & 0.278 & 0.493 & 0.507 \\
\hline 2008 & 144,677 & 155,477 & 0.158 & 0.212 & 0.482 & 0.518 \\
\hline 2009 & 121,613 & 145,139 & -0.159 & -0.066 & 0.456 & 0.544 \\
\hline 2010 & 177,384 & 192,254 & 0.459 & 0.325 & 0.480 & 0.520 \\
\hline 2011 & 200,294 & 246,779 & 0.129 & 0.284 & 0.448 & 0.552 \\
\hline 2012 & 200,586 & 280,260 & 0.001 & 0.136 & 0.417 & 0.583 \\
\hline 2013 & 205,778 & 329,419 & 0.026 & 0.175 & 0.384 & 0.616 \\
\hline 2014 & 218,077 & 430,796 & 0.060 & 0.308 & 0.336 & 0.664 \\
\hline 2015 & 216,488 & 433,286 & -0.007 & 0.006 & 0.333 & 0.667 \\
\hline 2016 & 207,275 & 449,833 & -0.043 & 0.038 & 0.315 & 0.685 \\
\hline
\end{tabular}

Source: World Trade Organization.

trade surplus. For example, the other business service is the top surplus with 186 billion dollars. The net export of construction is 154 billion dollars and the communications, computer and information service is 86 billion dollars. Although the service trade in China presents a deficit currently, we find that emerging service trade has been increasing rapidly and the structure of the service trade has become more balanced.

In terms of export of the sub-sectors, intellectual property and construction constitute the top growth rate as they are 308 percent and 89 percent, respectively (see Column (5) of Table 3). Compared to them, the import growth is different from the export's growth (see Column (7) of Table 3). As shown in Table 3, the top growth is communication, computer and information services with 52.5 percent, following by the personal, cultural, and recreational services (28.6\%). 
Table 2. The share of trade in China, 1995-2016 (Million \$).

\begin{tabular}{|c|c|c|c|c|c|c|}
\hline \multirow{2}{*}{ Year } & \multirow{2}{*}{$\begin{array}{l}\text { Service } \\
\text { Trade }\end{array}$} & \multirow{2}{*}{$\begin{array}{c}\text { Merchandise } \\
\text { Trade }\end{array}$} & \multicolumn{2}{|c|}{ Share } & \multicolumn{2}{|c|}{ Share Growth Rate } \\
\hline & & & Service & Merchandise & Service & Merchandise \\
\hline 1995 & 44,080 & 280,864 & 0.136 & 0.864 & ------ & ----- \\
\hline 1996 & 44,068 & 289,881 & 0.132 & 0.868 & -0.027 & 0.004 \\
\hline 1997 & 53,577 & 325,162 & 0.141 & 0.859 & 0.072 & -0.011 \\
\hline 1998 & 51,661 & 323,949 & 0.138 & 0.862 & -0.028 & 0.005 \\
\hline 1999 & 58,573 & 360630 & 0.140 & 0.860 & 0.016 & -0.003 \\
\hline 2000 & 67,664 & 474,297 & 0.125 & 0.875 & -0.106 & 0.017 \\
\hline 2001 & 73,744 & 509,651 & 0.126 & 0.874 & 0.012 & -0.002 \\
\hline 2002 & 87,629 & 620,766 & 0.124 & 0.876 & -0.021 & 0.003 \\
\hline 2003 & 103,808 & 850,988 & 0.109 & 0.891 & -0.121 & 0.017 \\
\hline 2004 & 140,277 & $1,154,555$ & 0.108 & 0.892 & -0.004 & 0.000 \\
\hline \multirow{2}{*}{ Year } & \multirow{2}{*}{$\begin{array}{l}\text { Service } \\
\text { Trade }\end{array}$} & \multirow{2}{*}{$\begin{array}{c}\text { Merchandise } \\
\text { Trade }\end{array}$} & \multicolumn{2}{|c|}{ Share } & \multicolumn{2}{|c|}{ Share Growth Rate } \\
\hline & & & Service & Merchandise & Service & Merchandise \\
\hline 2005 & 161,322 & $1,421,906$ & 0.102 & 0.898 & -0.059 & 0.007 \\
\hline 2006 & 193,824 & $1,760,439$ & 0.099 & 0.901 & -0.027 & 0.003 \\
\hline 2007 & 253,164 & $2,176,572$ & 0.104 & 0.896 & 0.051 & -0.006 \\
\hline 2008 & 300,154 & $2,563,260$ & 0.105 & 0.895 & 0.006 & -0.001 \\
\hline 2009 & 266,752 & $2,207,535$ & 0.108 & 0.892 & 0.028 & -0.003 \\
\hline 2010 & 369,638 & $2,974,001$ & 0.111 & 0.889 & 0.025 & -0.003 \\
\hline 2011 & 447,073 & $3,641,865$ & 0.109 & 0.891 & -0.011 & 0.001 \\
\hline 2012 & 480,846 & $3,867,119$ & 0.111 & 0.889 & 0.011 & -0.001 \\
\hline 2013 & 535,197 & $4,158,995$ & 0.114 & 0.886 & 0.031 & -0.004 \\
\hline 2014 & 648,873 & $4,301,526$ & 0.131 & 0.869 & 0.150 & -0.019 \\
\hline 2015 & 649,774 & $3,953,034$ & 0.141 & 0.859 & 0.077 & -0.012 \\
\hline 2016 & 657,108 & $3,685,557$ & 0.151 & 0.849 & 0.072 & -0.012 \\
\hline
\end{tabular}

Source: World Trade Organization.

\section{Methodology}

In general, the ratio of the import and export of service trade to $G D P$ is used to represent the openness. However, in the belt and road initiative, international investment is also key factor (China, National Bureau of Statistics). In this paper, we will take it into consideration.

$$
S O=\frac{S E_{c}+S I_{c}+S F D I_{f}+S F D I_{f}}{G D P}
$$

where

$S O$ refers to real openness of the service trade;

$S E_{c}$ means export of service trade;

$S I_{c}$ is import of service trade;

$S F D I_{f}$ refers to inflow of foreign investment in service industry;

$S F D I_{c}$ means the outflow of foreign investment in service industry. 
Table 3. Sub-sectors of the service trade in China, 2017 (Billion \$).

\begin{tabular}{|c|c|c|c|c|c|c|c|}
\hline \multirow{2}{*}{ Service Trade Category } & \multicolumn{2}{|c|}{ Import and Export } & \multicolumn{2}{|c|}{ Export } & \multicolumn{2}{|c|}{ Import } & \multirow{2}{*}{$\begin{array}{l}\text { Net } \\
\text { Export }\end{array}$} \\
\hline & Value & Growth & Value & Growth & Value & Growth & \\
\hline Total & 6957 & 0.050 & 2281 & 0.090 & 4676 & 0.034 & -2395.0 \\
\hline Processing service & 183 & -0.027 & 181 & -0.030 & 2 & 0.123 & 179.0 \\
\hline Maintenance services & 82 & 0.161 & 59 & 0.180 & 23 & 0.124 & 36.0 \\
\hline Transportation & 1300 & 0.137 & 371 & 0.100 & 929 & 0.153 & -558.0 \\
\hline Travel & 2935 & -0.039 & 387 & -0.130 & 2548 & -0.024 & -2161.0 \\
\hline Construction & 325 & 0.552 & 240 & 0.890 & 86 & 0.036 & 154.0 \\
\hline $\begin{array}{c}\text { Insurance and Pension } \\
\text { Services }\end{array}$ & 145 & -0.153 & 40 & -0.030 & 104 & -0.193 & -64.0 \\
\hline Financial services & 53 & 0.013 & 37 & 0.150 & 16 & -0.205 & 21.0 \\
\hline \multirow{2}{*}{ Service Trade Category } & \multicolumn{2}{|c|}{ Import and Export } & \multicolumn{2}{|c|}{ Export } & \multicolumn{2}{|c|}{ Import } & Net \\
\hline & Value & Growth & Value & Growth & Value & Growth & Export \\
\hline $\begin{array}{l}\text { Communication, } \\
\text { Computer and } \\
\text { Information Services }\end{array}$ & 469 & 0.200 & 278 & 0.050 & 192 & 0.525 & 86.0 \\
\hline Other Business Services & 1044 & 0.030 & 615 & 0.060 & 429 & -0.013 & 186.0 \\
\hline $\begin{array}{l}\text { Personal, Cultural, and } \\
\text { Recreational Services }\end{array}$ & 35 & 0.218 & 8 & 0.020 & 28 & 0.286 & -20.0 \\
\hline Government Services n.i.e. & 52 & 0.263 & 17 & 0.410 & 35 & 0.203 & -18.0 \\
\hline
\end{tabular}

Source: China, Ministry of Commerce, $2017^{1}$.

Considering the factor of scale economy, we use $(1-m / N)$ to adjust the formula (1). We also use purchasing power parity to calculate GDP because of the exchange rate. The results are shown in Table 4.

$$
S O=\frac{S E_{c}+S I_{c}+S F D I_{f}+S F D I_{f}}{G D P_{g}} \times \frac{1}{1-G D P_{g} / W G D P_{g}}
$$

Table 4 presents the real openness of service trade in China from 1995 to 2016. We find that the degree of the real openness is increasing in the whole. The real openness is 3.22 percent in 1995 and 5.15 percent in 2016, which has grown by 60 percent in a time span of 22 years.

According to Section 2, we try to adopt the competitiveness, export of service trade (GE) and structure of service trade (EMER) to measure the development of service trade in China. For the export, we will use the growth rate and for the structure, we will choice the proportion of emerging services. There are many ways to measure the competitiveness. One of the conventional methods is the revealed indices, including trade competitive index (TC), revealed comparative advantage index (RCA) and competitive advantage index (CA). Trade competitiveness index refers to the proportion of the difference between import and export to the total trade in a country. The revealed comparative advantage index excludes the impact of national and the world economy volatility, which could http://data.mofcom.gov.cn/fwmy/overtheyears.shtml 
Table 4. Real openness in China, 1995-2016 (\%).

\begin{tabular}{cccccccccccc}
\hline Year & 1995 & 1996 & 1997 & 1998 & 1999 & 2000 & 2001 & 2002 & 2003 & 2004 & 2005 \\
\hline Real Openness & 3.22 & 2.91 & 3.04 & 2.77 & 2.75 & 2.77 & 2.73 & 2.91 & 3.05 & 3.53 & 3.71 \\
Year & 2006 & 2007 & 2008 & 2009 & 2010 & 2011 & 2012 & 2013 & 2014 & 2015 & 2016 \\
Real Openness & 3.97 & 4.61 & 5.34 & 4.61 & 5.33 & 5.44 & 5.43 & 5.42 & 5.37 & 5.16 & 5.15 \\
\hline
\end{tabular}

reflect the comparative advantage of the industry. As Balassa excludes the factor of import, the competitive advantage index is proposed, which gives a real competitive advantage. Table 5 describes the calculation methods and competitiveness of these indices.

Another method to measure competitiveness is analytical indicators, which explain the reason for the competitiveness. However, both revealed indices and analytical indicators could not make a comprehensive measurement. Unlike the traditional methods, in this paper, we apply the Analytic Hierarchy Process (AHP) to estimate competitiveness in service trade. The results are shown in Table 6.

$$
\begin{gathered}
S T=\sum W_{i} S I_{i}, \sum W_{i}=1 \\
S I_{i}=\frac{S C_{i}}{S C_{i s}}
\end{gathered}
$$

where

$S T$ refers to competitiveness;

$W_{i}$ is the weight;

$S C_{i}$ means individual service trade competitiveness value;

$S C_{i s}$ represents individual competitiveness standard value.

Table 6 shows the competitiveness of service trade in China from 1995 to 2016. We find that the competitiveness is increasing in the whole. It is 1.56 in 1995 while in 2016, it achieves to 2.97. The competitiveness has grown by 90 percent in a time span of 22 years.

Various variables are incorporated into the VEC models according to the research focus. We try to augment the human capital (HC), total import and export of goods (GEM) as control variables. Considering that the belt and road initiative is proposed in 2013, we use a dummy variable (XN) to get the policy effects. Table 7 provides the descriptive statistics for all variables.

\section{Econometric Models and Empirical Results}

\subsection{Econometric Models}

In this section, we try to consider a general specification of ap-dimensional dynamic linear simultaneous equation model:

$$
A Y_{t}=\mu+A_{1} Y_{t-1}+\cdots+A_{m} Y_{t-m}+\delta_{t}
$$

where $Y_{t}=\left(y_{1, t}, y_{2, t}, \cdots, y_{p, t}\right)^{\prime}$ and $\delta_{t} \sim N\left(0, I_{p}\right)$. For the structural model (5), the reduced form model is: 
Table 5. Competitiveness index.

\begin{tabular}{|c|c|c|c|}
\hline Index & Calculation Methods & Variable Description & Competitiveness \\
\hline$T C$ & $T C=\left(X_{i j}-M_{i j}\right) /\left(X_{i j}+M_{i j}\right)$ & $\begin{array}{l}X_{i j}: \text { export of product } j \text { in country } i \\
M_{i j}: \text { import of product } j \text { in country } i\end{array}$ & $\begin{array}{l}\text { weak: }(-1,0) \\
\text { strong: }(0,1)\end{array}$ \\
\hline$R C A$ & $R C A=\left(X_{i j} / X_{t i}\right) /\left(X_{w j} / X_{t w}\right)$ & $\begin{array}{l}X_{t i}: \text { total export in country } i \\
X_{w j}: \text { export of product } j \text { in the world } \\
X_{t w}: \text { total export in the world }\end{array}$ & $\begin{array}{l}\text { weak: }(-\infty, 0.8) \\
\text { strong: }(0.8,2.5) \\
\text { stronger: }(2.5,+\infty)\end{array}$ \\
\hline$C A$ & $C A=R C A-\left(M_{i j} / M_{t i}\right) /\left(M_{w j} / M_{t w}\right)$ & $\begin{array}{l}M_{t i}: \text { total import in country } i \\
M_{w j}: \text { import of product } j \text { in the world } \\
M_{t w}: \text { total import in the world }\end{array}$ & $\begin{array}{l}\text { weak: }(-\infty, 0) \\
\text { strong: }(0,+\infty)\end{array}$ \\
\hline
\end{tabular}

Table 6. Competitiveness in China, 1995-2016.

\begin{tabular}{cccccccccccc}
\hline Year & 1995 & 1996 & 1997 & 1998 & 1999 & 2000 & 2001 & 2002 & 2003 & 2004 & 2005 \\
\hline Competitiveness & 1.56 & 0.95 & 1.25 & 1.14 & 1.16 & 1.08 & 1.04 & 0.99 & 0.97 & 0.88 & 0.83 \\
Year & 2006 & 2007 & 2008 & 2009 & 2010 & 2011 & 2012 & 2013 & 2014 & 2015 & 2016 \\
Competitiveness & 0.88 & 0.87 & 0.92 & 1.17 & 0.87 & 1.23 & 1.9 & 2.57 & 2.57 & 2.73 & 2.97 \\
\hline
\end{tabular}

Table 7. The descriptive statistics.

\begin{tabular}{ccccccccc}
\hline Variables & ST & GE & EMGR & SO & HC & GEM & XN \\
\hline Mean & 1.39 & 0.14 & 2.64 & 4.06 & 8.93 & $1,904,642.99$ & 0.15 \\
Median & 1.11 & 0.15 & 2.61 & 3.84 & 8.17 & $1,591,172$ & 0 \\
Maximum & 2.97 & 0.46 & 3.84 & 5.44 & 16.40 & $4,301,527.35$ & 1 \\
Minimum & 0.83 & -0.16 & 1.36 & 2.73 & 3.21 & 280,864 & 0 \\
Stand. dev. & 0.69 & 0.15 & 0.70 & 1.12 & 4.31 & $1,495,947.78$ & 0.35 \\
\hline
\end{tabular}

Note 1: Stand. dev.: Standard Deviation. Note 2: The data on human capital comes from Human Capital Report, China, 2017; The data on import and export of goods and per capita gross domestic product come from China, Bureau of Statistics.

$$
Y_{t}=\mu^{*}+A_{1}^{*} Y_{t-1}+\cdots+A_{m}^{*} Y_{t-m}+\theta_{t}
$$

where $\mu^{*}=A^{-1} \mu, A_{i}^{*}=A^{-1} A_{i}, \theta_{t}=A^{-1} \delta_{t}$ and $\operatorname{cov}(\theta)=A^{-1} A^{\prime-1}=\Omega$. The reduced form model (2) is a standard VAR model in levels which can be re-parameterized as:

$$
\Delta Y_{t}=\mu^{*}+\pi Y_{t-1}+\pi_{1} \Delta Y_{t-1}+\cdots+\pi_{m-1} \Delta Y_{t-m+1}+\theta_{t}
$$

where $\Delta$ is the first different operator, $\pi=\left(A_{1}^{*}+\cdots+A_{m}^{*}-I_{p}\right)$ and $\pi_{i}=-\left(A_{i+1}^{*}+\cdots+A_{m}^{*}\right)$. If the series are cointegrated, then $0<r=\operatorname{rank}(\pi)<p$ and (7) is a vector-error correction(VEC) model. In this case, there are $r$ cointegrating relationships and $k=p-r$ common trends among the series.

In particular, $\pi=\alpha \beta^{\prime}$, where $\alpha$ and $\beta$ are $(p \times r)$ matrices, the columns of $\beta$ are the coefficients in co-integrating vectors and the rows of $\alpha$ are the loadings on the error correction terms $\beta Y_{t-1}$ in each equation. 
In order to construct the system, stationarity must be satisfied by all the constituent time series, as non-stationary series would result in incorrect estimates of the standard errors. For this reason, the variables used are transformed firstly to their natural logarithm forms, which may eliminate bias of the estimation results. Then we deploy the conventional Augmented Dickey-Fuller test (ADF) to ascertain unit roots, where a time-series variable attains stationarity and effect of autocorrelation is excluded [16]. The test involves estimation of the following regression equation:

$$
\Delta Y_{t}=\rho Y_{t-1}+\mu_{t}
$$

where

$\Delta$ is the first difference fliter;

$Y$ is the series for test;

$t=1,2, \cdots, T$ represents the year;

$\rho$ is the coefficient;

$\mu_{t}$ represents residual term.

The results are shown in Table 8. It indicates that all variables are integrated of order two, which means the variables become stationary after the second differencing.

The existence of I (2) implies the possibility of co-integration among these variables. The co-integration test is applied to ascertain the presence of a long-run equilibrium relationship among them. Hence, we perform a co-integration test to identify a long equilibrium relationship among variables in time series. It should be noted that prior to estimation, the number of lag lengths needs to be specified. We choose lagged stage three, which minimizes the standard Akaike Information Criterion and Schwartz Bayesian Information Criterion. Tables 9-11 are the results of co-integration test. Table 9 presents that the competitiveness, openness, human capital and total import and export of goods have a long-run equilibrium relationship. Table 10 presents that the growth of export, openness, human capital and total import and export of goods have a long-run equilibrium relationship. Table 11 presents that the emerging service trade, openness, human capital and total import and export of goods have a long-run equilibrium relationship.

\subsection{Empirical Results}

After identifying the long-term equilibrium relationship among the variables, we try to use the error correction model (VECM)to reflect the short-term dynamic relationship. Since that the belt and road initiative is released in 2013 and there is a need to study its short-term effects on service trade in China. Estimation results of VECM are in Tables 12-14.

From Table 12, we find that the openness contributes to the competitiveness before the year of 2013 (see Column (2) of Table 12). When openness increases by 1 percent, competitiveness increases by 1.64 percent. The competitiveness will increase to 6.73 percent after the belt and road initiative. It indicates that this 
Table 8. Results of unit root tests.

\begin{tabular}{|c|c|c|c|}
\hline Variables & Level & $\mathrm{ADF}$ & Inferences \\
\hline \multirow{3}{*}{ ST } & $\mathrm{LD}$ & 0.9284 & \multirow{3}{*}{$\mathrm{I}(2)$} \\
\hline & FD & 0.0283 & \\
\hline & SD & $0.0216^{\star}$ & \\
\hline \multirow{3}{*}{ GE } & $\mathrm{LD}$ & 0.0160 & \multirow{3}{*}{$\mathrm{I}(2)$} \\
\hline & FD & 0.0043 & \\
\hline & $\mathrm{SD}$ & 0.0535 & \\
\hline \multirow{3}{*}{ EMER } & $\mathrm{LD}$ & 0.0062 & \multirow{3}{*}{$\mathrm{I}(2)$} \\
\hline & FD & 0.2178 & \\
\hline & SD & $0.0507^{\star}$ & \\
\hline \multirow{3}{*}{ SO } & $\mathrm{LD}$ & 0.5999 & \multirow{3}{*}{$\mathrm{I}(2)$} \\
\hline & FD & 0.0206 & \\
\hline & SD & $0.0083^{\star}$ & \\
\hline \multirow{3}{*}{$\mathrm{HC}$} & $\mathrm{LD}$ & 1.0000 & \multirow{3}{*}{$\mathrm{I}(2)$} \\
\hline & FD & 0.2448 & \\
\hline & SD & $0.0028^{\star}$ & \\
\hline \multirow{3}{*}{ GEM } & $\mathrm{LD}$ & 0.9859 & \multirow{3}{*}{$\mathrm{I}(2)$} \\
\hline & FD & 0.0479 & \\
\hline & SD & $0.0029^{*}$ & \\
\hline
\end{tabular}

Note 1: LD: indicates level data; FD: indicates first difference data; SD: indicates second difference data. Note 2: The hypotheses of Augmented Dickey-Fuller (ADF) test assumes that $\mathrm{H}_{0}$ : Non-stationary series (presence of unit root) versus $\mathrm{H}_{1}$ : Stationary series. The time series include a trend and intercept. Note 3: * indicates statistical significance at $10 \%$; and I (2) indicates integration of order two.

Table 9. Co-integration test result I.

\begin{tabular}{|c|c|c|c|c|c|c|c|}
\hline \multirow{2}{*}{$\frac{\text { Hypothesized }}{\text { No. of CE(s) }}$} & \multirow{2}{*}{$\begin{array}{c}\text { Trace } \\
\text { Statistic }\end{array}$} & \multirow{2}{*}{$\begin{array}{l}0.05 \text { Critical } \\
\text { Value }\end{array}$} & \multirow{2}{*}{ Prob.** } & \multirow{2}{*}{$\frac{\text { Hypothesized }}{\text { No. of CE(s) }}$} & \multirow{2}{*}{$\begin{array}{c}\text { Max-Eigen } \\
\text { Statistic }\end{array}$} & \multirow{2}{*}{$\begin{array}{c}0.05 \\
\text { Critical } \\
\text { Value }\end{array}$} & \multirow{2}{*}{ Prob. ${ }^{* *}$} \\
\hline & & & & & & & \\
\hline None ${ }^{*}$ & 65.97247 & 47.85613 & 0.0004 & None ${ }^{*}$ & 27.69546 & 27.58434 & 0.0484 \\
\hline At most $1^{\star}$ & 38.27702 & 29.79707 & 0.0042 & At most 1 & 17.15404 & 21.13162 & 0.1649 \\
\hline At most $2^{*}$ & 21.12297 & 15.49471 & 0.0064 & At mo & 12.57958 & 14.2646 & 0.0907 \\
\hline At most $3^{*}$ & 8.543395 & 3.841466 & 0.0035 & At most $3^{*}$ & 8.543395 & 3.841466 & 0.0035 \\
\hline At most $4^{*}$ & 65.97247 & 47.85613 & 0.0004 & At most $4^{*}$ & 27.69546 & 27.58434 & 0.0484 \\
\hline
\end{tabular}

Table 10. Co-integration test result II.

\begin{tabular}{|c|c|c|c|c|c|c|c|}
\hline \multirow{2}{*}{$\begin{array}{l}\text { Hypothesized } \\
\text { No. of CE(s) }\end{array}$} & \multirow{2}{*}{$\begin{array}{c}\text { Trace } \\
\text { Statistic }\end{array}$} & \multirow{2}{*}{$\begin{array}{c}0.05 \text { Critical } \\
\text { Value }\end{array}$} & \multirow{2}{*}{ Prob. ${ }^{* *}$} & \multirow{2}{*}{$\begin{array}{l}\text { Hypothesized } \\
\text { No. of CE(s) }\end{array}$} & \multirow{2}{*}{$\begin{array}{l}\text { Max-Eigen } \\
\text { Statistic }\end{array}$} & \multirow{2}{*}{$\begin{array}{c}0.05 \\
\text { Critical } \\
\text { Value }\end{array}$} & \multirow{2}{*}{ Prob. ${ }^{* *}$} \\
\hline & & & & & & & \\
\hline Non & 6 & & 0007 & None ${ }^{*}$ & 27.8261 & 27. & 0.0466 \\
\hline At most $1^{*}$ & 36.45 & 29.79 & 74 & At $m$ & 20.39213 & 21.13162 & 0.0632 \\
\hline At most $2^{*}$ & 16.06721 & 15.49471 & & & & 14.264 & 0.0829 \\
\hline At most 3 & 3.225599 & 3.841466 & 0.0725 & At most 3 & 3.225599 & 3.841466 & 0.0725 \\
\hline
\end{tabular}


Table 11. Co-integration test result III.

\begin{tabular}{|c|c|c|c|c|c|c|c|}
\hline Hypothesized & \multirow{2}{*}{$\begin{array}{c}\text { Trace } \\
\text { Statistic }\end{array}$} & \multirow{2}{*}{$\begin{array}{l}0.05 \text { Critical } \\
\text { Value }\end{array}$} & \multirow{2}{*}{ Prob. ${ }^{* *}$} & \multirow{2}{*}{$\begin{array}{c}\text { Hypothesized } \\
\text { No. of CE(s) }\end{array}$} & \multirow{2}{*}{$\begin{array}{l}\text { Max-Eigen } \\
\text { Statistic }\end{array}$} & \multirow{2}{*}{$\begin{array}{c}0.05 \\
\text { Critical } \\
\text { Value }\end{array}$} & \multirow{2}{*}{ Prob. ${ }^{\star *}$} \\
\hline No. of $\mathrm{CE}(\mathrm{s})$ & & & & & & & \\
\hline None ${ }^{*}$ & 60.97 & 47.8 & 0.0019 & None ${ }^{*}$ & 37.45269 & 27.58434 & 0.0020 \\
\hline At most 1 & 23.5185 & 29. & 0.22 & At most 1 & 16.7139 & 21.13162 & 0.1859 \\
\hline At most 2 & 6.80464 & 15.49471 & 0.6005 & At most 2 & 6.632084 & 14.2646 & 0.5335 \\
\hline At most 3 & 0.172556 & 3.841466 & 0.6778 & At most 3 & 0.172556 & 3.841466 & 0.6778 \\
\hline
\end{tabular}

Note $1:{ }^{*}$ denotes rejection of the hypothesis at the 0.05 level.

Table 12. VECM estimation result I.

\begin{tabular}{ccccc}
\hline & DST & DSO & DHC & DGEM \\
\hline \multirow{2}{*}{ DST $(-1)$} & -0.247817 & -0.002765 & 0.054086 & -0.316369 \\
& {$[-0.71589]$} & {$[-0.01232]$} & {$[3.01058]$} & {$[-1.04197]$} \\
DSO $(-1)$ & 1.649503 & -0.439629 & -0.078429 & -0.987751 \\
& {$[2.18117]$} & {$[-0.89676]$} & {$[-1.99828]$} & {$[-1.48911]$} \\
DHC $(-1)$ & -12.11711 & 1.773241 & 0.822965 & 1.436226 \\
& {$[-2.72597]$} & {$[0.61538]$} & {$[3.56737]$} & {$[0.36837]$} \\
DGEM $(-1)$ & -0.371984 & 0.24802 & 0.018466 & 0.402408 \\
& {$[-0.67101]$} & {$[0.69016]$} & {$[0.64182]$} & {$[0.82759]$} \\
XN*DSO (-1) & 6.732781 & 2.172702 & -0.966334 & 9.129725 \\
R-squared & {$[1.71286]$} & {$[0.55399]$} & {$[-3.07763]$} & {$[1.72046]$} \\
\hline
\end{tabular}

initiative has enhanced the impact of openness on competitiveness in service trade.

From Table 13, we find that the openness has a negative influence on export growth at first (see Column (2) of Table 13). When openness increases by 1 percent, export growth decreases by 2.38 percent. However, the export growth will increase to 2.98 percent when we take the belt and road initiative into consideration. It shows that the initiative has improved the impact of openness on export growth.

From Table 14, we find that openness optimizes the service trade structure before the belt and road initiative (see Column (2) of Table 14). When openness increases by 1 percent, export growth increases by 0.22 percent. However, it decreases the growth rate to 7.99 percent after the year of 2013. It shows that the belt and road initiative has reduced the impact of openness on the service trade structure.

The above discussions give a snapshot of the statistical significance of historical changes, however, it does not indicate whether or not any particular series responds to perturbations or unexpected changes (i.e., the shocks) in another series. Hence, we deploy generalized impulse response functions (GRIFS) to address this shortcoming. The use of GIRFs is to trace the effect of a one-off shock to one of the innovations on the current and future values of the endogenous variables. Figures 1-3 display the results of the GRIFS for competitiveness, growth of export and the emerging service trade. 
Table 13. VECM estimation result II.

\begin{tabular}{ccccc}
\hline & $\mathrm{D}(\mathrm{GE})$ & $\mathrm{DSO}$ & $\mathrm{DHC}$ & DGEM \\
\hline \multirow{2}{*}{ DGE $(-1)$} & 0.040091 & 0.078665 & -0.034742 & 0.256861 \\
& {$[0.20330]$} & {$[0.58280]$} & {$[-2.43010]$} & {$[1.44678]$} \\
DSO $(-1)$ & -2.380311 & -0.43855 & -0.073679 & -1.140097 \\
& {$[-3.35479]$} & {$[-0.90304]$} & {$[-1.43238]$} & {$[-1.78484]$} \\
DH $(-1)$ & 6.12973 & 1.285452 & 0.725317 & 0.902632 \\
& {$[1.83610]$} & {$[0.56256]$} & {$[2.99686]$} & {$[0.30032]$} \\
DGEM $(-1)$ & 0.633846 & 0.261142 & -0.006521 & 0.29052 \\
& {$[1.06594]$} & {$[0.64163]$} & {$[-0.15126]$} & {$[0.54269]$} \\
XN*DSO & 2.98279 & 1.921581 & -0.283995 & 6.349204 \\
& {$[1.68945]$} & {$[0.64893]$} & {$[-0.90547]$} & {$[1.63014]$} \\
R-squared & 0.778651 & 0.172663 & 0.85461 & 0.493174 \\
\hline
\end{tabular}

Table 14. VECM estimation result III.

\begin{tabular}{ccccc}
\hline & DEMER & DSO & DGEM & DHC \\
\hline \multirow{2}{*}{ DEMER $(-1)$} & -0.367394 & -0.021153 & -0.198118 & 0.020104 \\
& {$[-4.31876]$} & {$[-0.18943]$} & {$[-1.31495]$} & {$[1.98283]$} \\
DSO $(-1)$ & 0.219324 & -0.843305 & -1.269741 & -0.276786 \\
& {$[-4.44490]$} & {$[-1.22966]$} & {$[-1.37221]$} & {$[0.41979]$} \\
DGEM $(-1)$ & -0.258988 & 0.224503 & 0.516911 & 0.03687 \\
& {$[-1.09121]$} & {$[0.72062]$} & {$[1.22971]$} & {$[1.30337]$} \\
DHC $(-1)$ & -2.472064 & 0.019545 & 1.382044 & 0.713977 \\
& {$[-1.99420]$} & {$[0.01201]$} & {$[0.62949]$} & {$[4.83240]$} \\
XN*DLNSO & -7.993967 & 0.319786 & 4.625899 & -0.589638 \\
\multirow{2}{*}{ R-squared } & {$[-3.34998]$} & {$[0.10209]$} & {$[1.09455]$} & {$[-2.07318]$} \\
& 0.901165 & 0.21862 & 0.496304 & 0.89909 \\
\hline
\end{tabular}

From Figure 1, we find that the response of competitiveness is increasing and positive when gives openness a shock at first. Then the competitiveness begins to fall and reach the minimum at the third period. After that, there is a violent fluctuation in three periods (period 4-period 6). The response of competitiveness tends to be stable from the seventh period. When human capital has a shock, the response is stable in general although it has a slight fluctuation. The response seems more volatile when gives the import and export of goods a shock.

From Figure 2, we study that the response of growth is decreasing and negative when gives openness a shock at first. Then it begins to go up and reach the maximum at the third period. After that, there is a fluctuation during period 4 and period 5. The response of growth rate tends to be stable from the sixth period. When human capital has a shock, the response has a violent fluctuation and reach the minimum at the fifth period. However, the response in the future is increasing and positive. The trend of response to the impulse of import and export of goods is opposite compared to the impulse of human capital.

From Figure 3, the trend of responses is opposite between the impulse of openness and human capital at the period of $1-6$. Specifically, when gives a shock to openness in the current period, the response of emerging service trade 

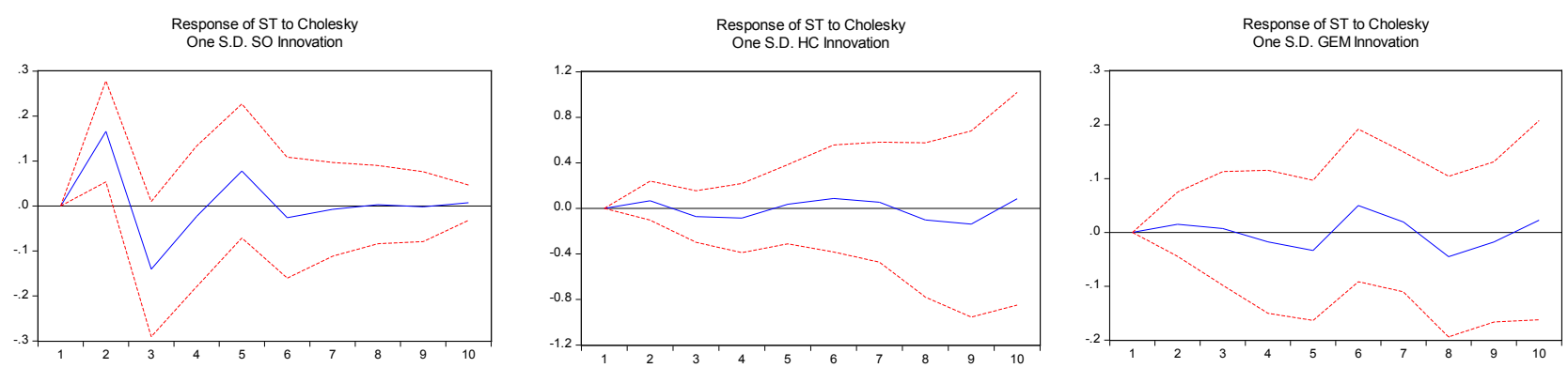

Figure 1. Plot of generalized impulse functions I.
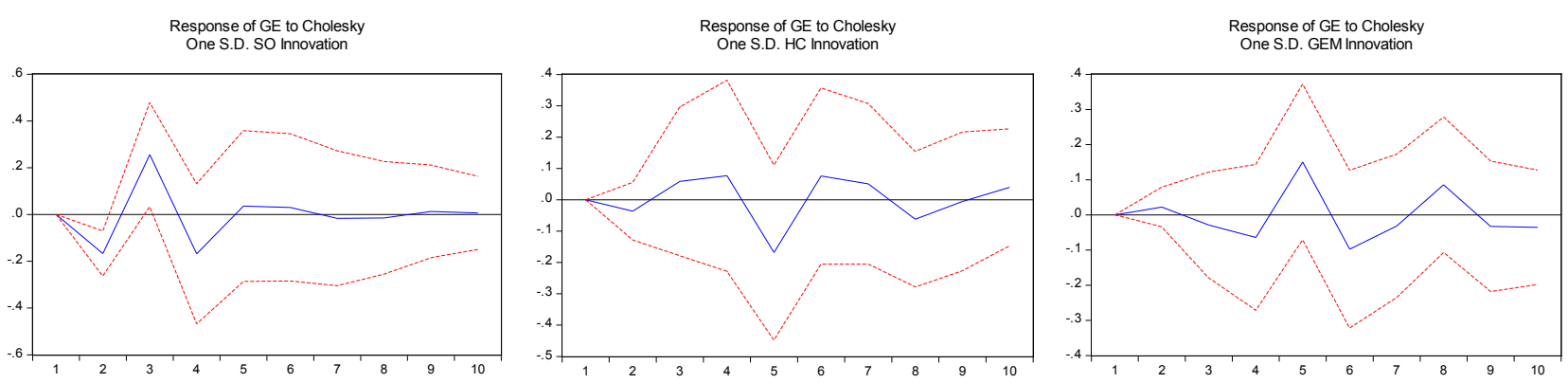

Figure 2. Plot of generalized impulse functions II.
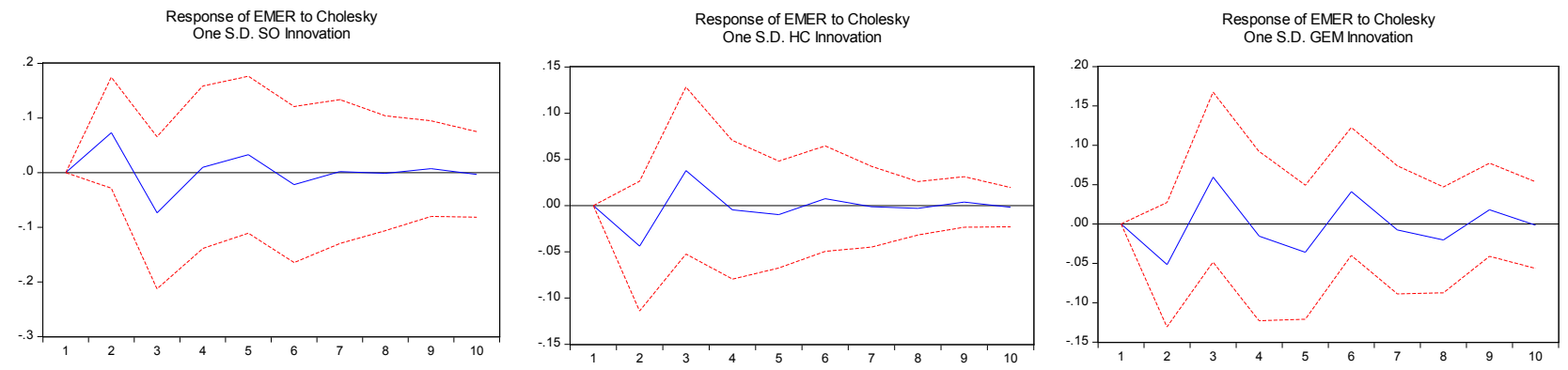

Figure 3. Plot of generalized impulse functions III.

is increasing. It gets the maximum at the second period. In the subsequent period, the response drops to be negative, which reaches minimum. The trend of response to human capital is exactly opposite in the first six periods. From the seventh period, both of them become stable gradually. The response to import and export of goods impulse fluctuates dramatically in the whole period.

From the empirical results above, we get that the belt and road initiative has enhanced the impact of openness on competitiveness in service trade, as well as the export growth. However, the real openness has a negative influence on the service trade structure after the year of 2013, which indicates that the emerging service structure does not have a significant optimization after the open-door policy carried out.

\section{Conclusions}

In this study, we try to investigate whether the belt and road initiative impacts 
service trade in China. Three dimensions including competitiveness, growth rate of services export and proportion of emerging services are used to measure service trade. Covering the period of 1995-2016 and using the variables of openness, human capital, import and export of goods and dummy variable, we employ vector-error correction (VEC) model and impulse response functions (GRIFS) to estimate.

We find that real openness plays a vital role in implementing the belt and road initiative as the competitiveness and export growth of service trade in China are increasing. Nevertheless, emerging services has no improvement after the belt and road initiative. It may be the reason that tourism service, as one of the traditional service trade, has risen significantly since 2013 (National Bureau of Statistics, China). Therefore, further study will be focused on how to improve the proportion of emerging services and optimize the structure of service trade under the belt and road initiative.

\section{Conflicts of Interest}

The authors declare no conflicts of interest regarding the publication of this paper.

\section{References}

[1] Arnold, J.M., Javorcik, B.S. and Mattoo, A. (2006) Does Services Liberalization Benefit Manufacturing Firms? Evidence from the Czech Republic. Journal of International Economics, 85, 136-146. https://doi.org/10.2139/ssrn.932031

[2] Mattoo, A., Rathindran, R. and Subramanian, A. (2006) Measuring Services Trade Liberalization and Its Impact on Economic Growth: An Illustration. Journal of Economic Integration, 21, 64-98. https://doi.org/10.11130/jei.2006.21.1.64

[3] Khoury, A.C.E. and Savvides, A. (2006) Openness in Services Trade and Economic Growth. Economics Letters, 92, 277-283. https://doi.org/10.1016/j.econlet.2006.03.003

[4] Bendavid, D. (1993) Equalizing Exchange: Trade Liberalization and Income Convergence. Quarterly Journal of Economics, 108, 653-679. https://doi.org/10.2307/2118404

[5] Jansen, M. and Piermartini, R. (2004) The Impact of Mode 4 Liberalization on Merchandise Trade and on Other Modes of Trade in Services. World Trade Organization, Geneva.

[6] Markusen, J., Rutherford and Tarrz, D. (2005) Trade and Direct Investment in Producer Services and the Domestic Market for Expertise. Canadian Journal of Economics, 38, 758-777. https://doi.org/10.1111/j.0008-4085.2005.00301.x

[7] Liu, L.G. (2005) The Impact of Financial Service Trade Liberalization on China. Discussion Papers.

[8] Lim, E.K. and Chen, Z. (2012) The Impact of Trade Liberalization in Telecommunications Services: The Case of APEC Countries. Telecommunications Policy, 36, 274-281. https://doi.org/10.1016/j.telpol.2012.01.003

[9] Chen, J. and Chen, D. (2017) Trade Openness, Economic Freedom and Economic Growth: Based on the Analysis of China and the "Along the Way" Countries. Journal of Wuhan University, 3, 46-57. 
[10] Zhang, L., Luo, M. and Yang, D. (2017) Impacts of Trade Liberalization on Chinese Economy with Belt and Road Initiative. Maritime Policy \& Management, 45, 301-318. https://doi.org/10.1080/03088839.2017.1396504

[11] Matheus, K. (2018) The Positive Impact of Trade Openness on Consumption of Energy: Fresh Evidence from Andean Community Countries. Energy, 158, 936-943. https://doi.org/10.1016/j.energy.2018.06.091

[12] Zou, C. (2008) Liberalization in Service Trade between China-ASEAN and the Competitiveness in Service Trade. Around Southeast Asia, 8, 49-53.

[13] Zhuang, M. (2014) A Research on the Competitiveness of China's Service Trade Based on Service Trade Openness. East China Economic Management, 28, 51-54.

[14] Balassa, B. (1965) Trade Liberalisation and "Revealed" Comparative Advantage. Manchester School, 33, 99-123. https://doi.org/10.1111/j.1467-9957.1965.tb00050.x

[15] Yao, Z. (2015) Impact of Increase in Real Openness of Service Industry upon Competitiveness of China's Service Industry. Journal of Beijing Technology and Business University, 30, 22-30.

[16] Dickey, D.A. and Fuller, W.A. (1979) Distribution of the Estimators for Autoregressive Time Series with a Unit Root. Journal of the American Statistical Association, 366, 427-431. https://doi.org/10.1080/01621459.1979.10482531 